\title{
Prevalence of Onodi Cells in Korean Based on Computed Tomography
}

\author{
Seung Ju Lee, Yong Kyung Kang, Eun Sub Lee, and Ji Sun Kim \\ Department of Otorhinolaryngology-Head and Neck Surgery, Eulji Hospital, Eulji University College of Medicine, Seoul, Korea
}

\section{한국인에서 오노디 세포의 유병률에 대한 영상학적 연구}

이승주 · 강용경 · 이은섭 · 김지선

을지대학교 의과대학 을지병원 이비인후과학교실

\author{
Received May 29, 2015 \\ Revised June 26, 2015 \\ Accepted June 27, 2015 \\ Address for correspondence \\ Ji Sun Kim, MD, PhD \\ Department of Otorhinolaryngology- \\ Head and Neck Surgery, Eulji Hospital, \\ Eulji University College of Medicine, \\ 68 Hangeulbiseok-ro, Nowon-gu, \\ Seoul 01830, Korea \\ Tel $+82-2-970-8276$ \\ Fax $+82-2-970-8275$ \\ E-mail vicky96@eulji.ac.kr
}

Background and Objectives The Onodi cell is the posterior-most ethmoid air cell that lies superior to the sphenoid sinus, and has intimate relationship with the optic nerve. The aim of this study was to evaluate Onodi cell prevalence, protrusion and bony dehiscence of the optic nerve in Korean population using computed tomography (CT).

Subjects and Method A retrospective analysis was performed on 129 Korean patients who consecutively underwent CT between January 2014 and December 2014. The presence of Onodi cells and protrusion and bony dehiscence of the optic nerve were analyzed using 3-dimensional CT images.

Results A total of 70 males and 59 females were studied. Onodi cells were present in 61 (47.3\%) patients but in $88 \mathrm{CT}$ slides (34.1\%); this consisted of 27 Onodi cells found bilaterally (44.3\%), 18 on the right side only (29.5\%), and 16 on the left only $(26.2 \%)$. Of the total 61 patients with Onodi cells, the optic nerve protrusion and dehiscence were present in $34.4 \%$ and $23.8 \%$ of the studied CT slides. There was no statistically significant relationship between the presence of Onodi cells and protrusion and bony dehiscence of the optic nerve.

Conclusion In our study, Onodi cells were found in almost half of the patients. This prevalence is higher than previously reported in the literature. In patients with Onodi cells, the optic nerve protrusion and dehiscence were present in about $1 / 3$ and $1 / 5$ of the total slides, respectively. Therefore, the identification of these cells is essential prior to endoscopic sinus and skull base surgery to prevent potential complications.

Korean J Otorhinolaryngol-Head Neck Surg 2015;58(12):855-8

Key Words Computed tomography $\cdot$ Onodi cells $\cdot$ Optic nerve $\cdot$ Sphenoid sinus.

\section{서 론}

오노디 세포(Onodi cell)는 접형동의 상외측으로 함기화되 어 가장 뒤쪽에 위치하는 사골동 세포이며, 접형동, 터키안, 내 경동맥 등 주위의 중요한 구조물들과 접하고 있다. 오노디 세 포는 특히 시신경과 밀접한 관계가 있으므로 오노디 세포염 (Onodi cell sinusitis)이 있을 경우 시각에 대한 증상이 나타 날 수도 있고, 오노디 세포에 발생한 점액종으로 인하여 갑자 기 시력을 상실한 증례도 보고되고 있다. ${ }^{1)}$ 접형동에 대한 수
술을 시행할 때 오노디 세포를 접형동으로 오인하게 되면 시 신경에 대한 손상의 가능성이 커지므로, 오노디 세포가 존재 하는 경우 수술이 어려워질 수 있다. 더욱이 시신경이 접형동 이나 오노디 세포로 돌출되고, 시신경 주위에 골결손이 있는 경우에는 수술 도중 신경에 손상을 받을 가능성이 더 높아질 수 있다.

최근 터키안(sella turcica)의 병변을 제거할 때 내시경적 비 강내 경접형동 접근법(endoscopic endonasal transsphenoidal approach)을 많이 사용하게 되면서 오노디 세포에 대한 관심 


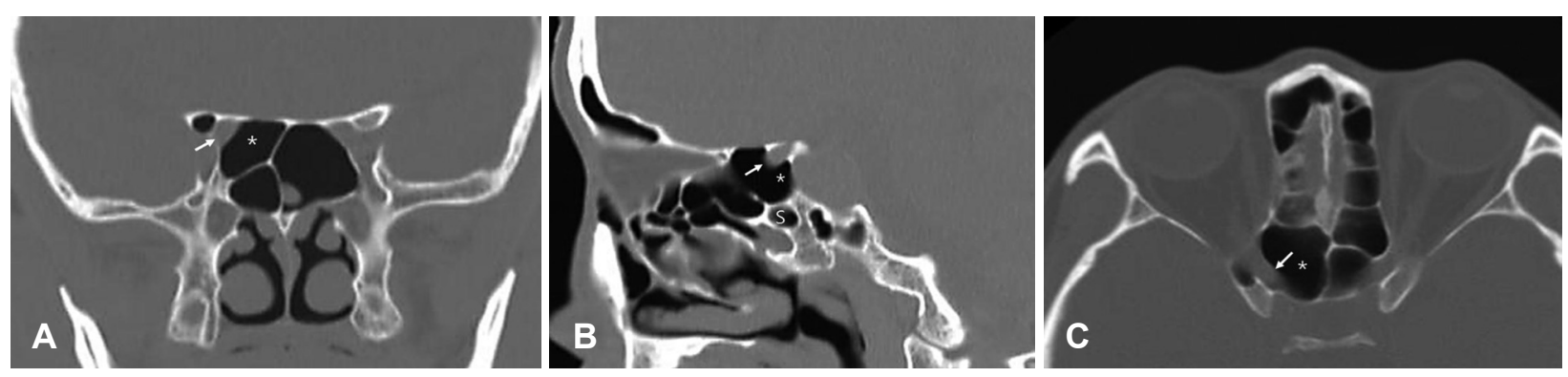

Fig. 1. Coronal (A), sagittal (B), and axial (C) computed tomography scan show a right Onodi cell (asterisks) above the sphenoid sinus (S). Protrusion and dehiscence of the right optic nerve (arrows) are also observed.

이 높아지고 있다. 이 경우 오노디 세포를 제거하여야 충분한 시야를 확보할 수 있다. ${ }^{2)}$ 따라서 부비동 내시경수술뿐만 아니 라 비강을 통해 터키안 또는 터키안 주위의(parasellar) 병변에 대하여 수술을 시행하기 전에 중요한 해부학적인 변이인 오노 디 세포의 존재 여부 및 시신경의 돌출이나 골결손을 미리 발 견하여 합병증을 예방하는 것이 중요하다.

아직까지 한국인에서 오노디 세포의 유병률에 대한 보고는 많지 않으며, 이에 대한 일관된 견해가 없다. Shin 등은 220 쪽의 영상 중 단지 28쪽(12.7\%)에서 오노디 세포를 발견하였 으나, Hwang 등)은 200쪽의 영상 중 64쪽(32\%)에서 오노디 세포를 발견하였다. 또한 한국인에서 오노디 세포와 연관된 시신경의 돌출이나 골결손의 빈도에 대해서는 전혀 연구가 되 어 있지 않다. 본 연구에서 저자들은 한국인을 대상으로 고해 상도 전산화단층촬영(computed tomography, CT) 영상을 분 석하여 오노디 세포의 유병률과 시신경의 돌출 및 골결손의 빈도를 알아보고자 하였다.

\section{대상 및 방법}

2014년 1월부터 2014년 12월까지 저자들의 외래로 내원한 129 명의 연속적인 한국인 성인 환자들의 부비동에 대하여 시 행한 고해상도 CT 영상을 분석하여 후향적 연구를 시행하였 다. 연구에 포함된 환자들의 나이, 성별, 검사 목적 등에 대한 정보를 수집하였다. 환자들은 비루, 비폐색, 후비루, 후각 소실, 두통, 안면통 등의 다양한 비증상으로 인하여 CT를 시행하였 다. GE Medical systems LightSpeed Ultra 16(GE Medical Systems, Milwaukee, WI, USA)을 이용하여, 경구개와 평행 인 축상면에 대하여 $2.5 \mathrm{~mm}$ 의 두께로 $(120 \mathrm{kVp}, 220 \mathrm{mAs}$, FOV $180 \times 180 \mathrm{~mm}$ ) 촬영하였다. GE workstation $\mathrm{Adw} 4.5$ software(GE Medical Systems)를 이용하여 $2 \mathrm{~mm}$ 의 두께로 시상면과 관상면 영상을 재구성하였다. 사골동이나 접형동에 혼탁이 있는 경우, 이전 수술이나 종양 등의 비염증성 질환에 의해 사골동이나 접형동 부위의 변형이 있는 경우, 외상의 과 거력이 있는 경우는 제외하였다. 이 연구를 위하여 환자의 자
료를 이용하는 것에 대해 본원의 임상시험 심사위원회로부터 승인을 받았다.

오노디 세포는 시신경과 접하고 있는 후사골동 세포로 정 의하였다. ${ }^{5)}$ 각각의 환자에서 축상면, 관상면, 시상면을 동시에 평가하여 오노디 세포의 유무 및 위치(우측, 좌측, 양측)를 결 정하였다. 오노디 세포가 있는 환자들을 대상으로 시신경이 접형동이나 오노디 세포로 돌출되었는지와 시신경 주위에 골 결손이 있는지를 조사하였다(Fig. 1). 관상면이나 시상면 영상 에서 시신경의 $50 \%$ 이상이 오노디 세포나 접형동 안으로 튀 어나온 경우를 돌출로 정의하였다.) 또한 오노디 세포가 있는 군과 없는 군에서 시신경의 돌출과 골결손의 빈도를 각각 구 하여 두 군 간에 차이가 있는지 알아보았다. 통계 분석은 SPSS 12.0(SPSS Inc., Chicago, IL, USA)을 이용하여 Fisher의 정 확 검증을 시행하였다. 통계의 유의성은 유의확률 0.05 미만 을 기준으로 하였다.

\section{결 과}

129 명의 환자를 대상으로 연구를 시행하였다. 남성이 70 (54.3\%)명, 여성은 59(45.7\%)명이었다. 연령 분포는 18세에서 81 세까지였으며 평균 연령은 39.3세였다. 129 명의 환자 중 61 명 (47.3\%)에서, 258쪽의 영상 중 88쪽(34.1\%)에서 오노디 세포가 발견되었다. 오노디 세포가 발견된 환자 중 31명(50.8\%)은 남 성이었고, 30명(49.2\%)은 여성이었다. 연령 분포는 21세에서 81 세까지였으며 평균 연령은 42.4세였다. 오노디 세포가 있는 환 자 중 27명(44.3\%)은 양측에서, 18명(29.5\%)은 우측에서만, 16 명(26.2\%)은 좌측에서만 오노디 세포가 발견되었다.

오노디 세포를 가지고 있는 61 명의 환자, 122 쪽의 영상 중 88 쪽(72.1\%)에서 오노디 세포가 발견되었고 34쪽(27.9\%)에서는 오노디 세포가 발견되지 않았다. 122쪽 중 42쪽(34.4\%)에서 시신경의 돌출이, 29쪽(23.8\%)에서 시신경의 골결손이 발견되 었다. 오노디 세포가 있는 군에서 오노디 세포로의 시신경의 돌출은 33쪽(37.5\%)에서 발견되었으며, 오노디 세포가 없는 군에서 접형동으로의 시신경의 돌출은 9쪽(26.5\%)에서 발견 
Table 1. The prevalence of protrusion and dehiscence of the optic nerve in a total of 61 patients with Onodi cells

\begin{tabular}{lcc}
\hline & Optic nerve protrusion, $\mathrm{n}(\%)$ & Optic nerve dehiscence, $\mathrm{n}(\%)$ \\
\hline Sides with Onodi cell $(\mathrm{n}=88)$ & $33(37.5)^{*}$ & $23(26.5)^{\dagger}$ \\
Sides without Onodi cell $(\mathrm{n}=34)$ & $9(26.5)^{*}$ & $6(17.6) \dagger$ \\
\hline Total sides $(\mathrm{n}=122)$ & $42(34.4)$ & $29(23.8)$ \\
\hline$* \mathrm{p}=0.293,{ }^{\dagger} \mathrm{p}=0.477$ & &
\end{tabular}

되었다. 오노디 세포의 유무와 시신경의 돌출은 통계학적으로 의미 있는 상관관계를 보이지 않았다 $(p=0.293)$. 오노디 세포 가 있는 군에서 시신경의 골결손이 23쪽(26.1\%)에서 발견되었 으며, 오노디 세포가 없는 군에서는 6쪽(17.6\%)에서 발견되었 다(Table 1). 오노디 세포의 유무와 시신경의 골결손은 통계학 적으로 의미 있는 상관관계를 보이지 않았다 $(p=0.477)$.

\section{고 찰}

현재까지 보고된 오노디 세포의 유병률은 연구자들마다 상 당한 차이를 보이고 있다. 이러한 차이에 대한 이유로 우선 연 구 방법에 따른 차이를 들 수 있다. CT를 이용한 연구에서는 오노디 세포의 유병률을 대개 $7 \%$ 에서 $24 \%$ 정도로 보고하고 있으나,-9) 사체를 이용한 연구에서는 이보다 높은 $42 \%$ 에서 60\% 정도로 보고하고 있다. ${ }^{10-12)}$ 내시경을 이용한 연구에서는 영상의 확대를 통하여 작은 구조물인 시신경관의 일부가 후 사골동으로 돌출되는 것을 더 정확하게 알 수 있으므로 $33.3 \%$ 에서 $42 \%$ 의 비교적 높은 오노디 세포의 유병률을 보고하고 있다. 28,13) 따라서 사체에서 또는 내시경을 통하여 발견할 수 있는 실제로 존재하는 오노디 세포를 CT에서는 발견하지 못 할 가능성이 있다고 생각된다.

둘째로, $\mathrm{CT}$ 를 이용한 연구에서도 상당한 차이를 보이는데 축상면과 관상면 영상만을 이용한 연구에서는 $7 \%$ 에서 $19.6 \%$ 의 낮은 유병률을 보인 반면, $5,7,1,14$ 시상면을 포함한 3차원적인 영상을 이용한 연구에서는 $65.3 \%$ 의 높은 유병률을 보였다. ${ }^{15}$ 따라서 축상면과 관상면 영상만으로는 오노디 세포를 확인하 기 힘들 수 있으며, 시상면을 포함한 3차원적인 영상을 이용 하여야 오노디 세포를 확실하게 판별할 수 있다고 생각된다. 본 연구에서도 3 차원적인 영상을 이용하였는데, 축상면보다 는 관상면과 시상면 영상이 유용하였으며, 관상면과 시상면 을 동시에 비교하는 것이 오노디 세포를 발견하는 가장 효과 적인 방법으로 생각된다.

셋째로, 연구자들마다 오노디 세포에 대한 정의에 차이를 보이고 있다. 오노디 세포를 시신경관의 자국(impression)이 있는 후사골동 세포로 엄격하게 정의한 연구도 있으나, ${ }^{8)}$ 시신 경의 돌출이나 골결손과 상관없이 접형동의 상방에 존재하는 후사골동 세포를 모두 오노디 세포로 느슨하게 정의한 연구
도 있다. ${ }^{15)}$ 본 연구에서는 시신경과 접하고 있는 후사골동 세 포를 오노디 세포로 정의하였다.

인종에 따른 차이도 있는데, 아시아인의 사체를 대상으로 한 연구에서 $51 \%$ 에서 $60 \%$ 의 높은 유병률이 보고되기도 하였 다. ${ }^{11,12}$ 한국인을 대상으로 한 연구는 많지 않은데, 최근 3차원 적인 영상을 이용한 연구의 결과가 발표되고 있다. 시신경과 상관없이 오노디 세포를 느슨하게 정의하였으나 영상의 쪽수 를 기준으로 $12.7 \%$ 의 낮은 유병률을 얻은 연구가 있다. ${ }^{3)}$ 또 다 른 연구에서는 내시경적 비강내 경접형동 접근법을 시행한 162 명의 환자 중 53 명(32.7\%)에서 수술 전에 $\mathrm{CT}$ 를 분석하여 오노디 세포를 발견하였고, 실제 수술을 시행하여 이와 거의 비슷한 54명(33.3\%), 77쪽(23.8\%)에서 오노디 세포를 발견하 였다. ${ }^{2)}$ 가장 최근의 연구에서는 영상의 쪽수를 기준으로 이보 다 높은 32\%의 유병률을 얻었다. ${ }^{4}$

본 연구에서는 한국인을 대상으로 시상면을 포함한 3차원 적인 분석을 시행하였고 시신경과 접하는 후사골동 세포만을 오노디 세포로 정의하여 지금까지 보고된 것에 비하여 가장 높은 47.3\%의 유병률을 얻었다. 한국인을 대상으로 한 연구에 서 위와 같은 유병률의 차이가 나는 이유는 알 수 없으나, 기 존의 연구에서는 각각 부비동 내시경 수술, 두개저 수술을 받 은 환자를 대상으로 하였고, 본 연구에서는 수술을 받은 환자 는 제외하고 $\mathrm{CT}$ 소견에서 후사골동과 접형동에 혼탁이 없는 환자들을 선택하였다는 점을 고려한다면, 연구에 포함된 환자 의 비강 및 부비동의 이환 상태가 다르다는 것이 하나의 이유 가 될 수 있다고 생각된다.

시신경은 매우 얇은 골조직에 의하여 오노디 세포나 접형동 과 분리되어 있다. 이러한 골조직에 결손이 발생하거나 시신경 이 부비동으로 돌출되는 경우 시신경에 대한 손상의 위험이 더 커질 수 있다. Unal 등과 과 Sirikci 등은 오노디 세포와 상 관없이 관상면과 축상면 $\mathrm{CT}$ 를 분석하여 쪽수를 기준으로 각 각 $31.3 \%, 25 \%$ 쪽에서 시신경의 돌출을, 각각 $22.8 \%, 20.1 \%$ 에 서 골결손을 발견하였다. Ozturan 등 $\left.{ }^{14}\right)$ 은 오노디 세포가 발견 된 160 명의 320쪽의 관상면 영상을 대상으로 연구를 시행하 였는데, 오노디 세포가 있는 212쪽의 80.1\%와 $17.6 \%$ 에서 각각 시신경의 돌출과 골결손을 발견한 반면, 오노디 세포가 없는 108 쪽의 영상에서는 $17.6 \%$ 와 $0 \%$ 에서 각각 시신경의 돌출과 골결손을 발견하였고, 오노디 세포가 있는 경우 시신경의 돌 
출과 골결손이 통계적으로 의미 있게 증가한다고 하였다. 본 연구에서는 쪽수를 기준으로 각각 $34.4 \%, 23.8 \%$ 에서 시신경 의 돌출과 골결손을 발견하였고, 연구대상이 다르므로 직접적 인 비교를 하기는 쉽지 않지만 Unal 등히 및 Sirikci 등화과 비 슷한 결과를 얻었다. 오노디 세포가 있는 경우 시신경의 돌출 과 골결손이 더 많았으나 Ozturan 등하의 연구와는 달리 통계 학적으로 의미 있는 차이를 보이지는 않았다.

\section{REFERENCES}

1) Klink T, Pahnke J, Hoppe F, Lieb W. Acute visual loss by an Onodi cell. Br J Ophthalmol 2000;84(7):801-2.

2) Shin JH, Kim SW, Hong YK, Jeun SS, Kang SG, Kim SW, et al. The Onodi cell: an obstacle to sellar lesions with a transsphenoidal approach. Otolaryngol Head Neck Surg 2011;145(6):1040-2.

3) Shin JM, Jang WI, Baek BJ. Analysis of sphenoid sinus and surrounding structures using multidetector computed tomography. Korean J Otorhinolaryngol-Head Neck Surg 2012;55(2):95-100.

4) Hwang SH, Joo YH, Seo JH, Cho JH, Kang JM. Analysis of sphenoid sinus in the operative plane of endoscopic transsphenoidal surgery using computed tomography. Eur Arch Otorhinolaryngol 2014;271(8):2219-25.

5) Unal B, Bademci G, Bilgili YK, Batay F, Avci E. Risky anatomic variations of sphenoid sinus for surgery. Surg Radiol Anat 2006; 28(2):195-201.

6) Sirikci A, Bayazit YA, Bayram M, Mumbuç S, Güngör K, Kanlikama M.
Variations of sphenoid and related structures. Eur Radiol 2000;10 (5):844-8

7) Tan KL, Harvinder S. Prevalence of onodi cells in hospital raja permaisuri bainun, ipoh, malaysia. Med J Malaysia 2010;65(2):101-2.

8) Driben JS, Bolger WE, Robles HA, Cable B, Zinreich SJ. The reliability of computerized tomographic detection of the Onodi (Sphenoethmoid) cell. Am J Rhinol 1998;12(2):105-11.

9) Pérez-Piñas, Sabaté J, Carmona A, Catalina-Herrera CJ, JiménezCastellanos J. Anatomical variations in the human paranasal sinus region studied by CT. J Anat 2000;197(Pt 2):221-7.

10) Kantarci M, Karasen RM, Alper F, Onbas O, Okur A, Karaman A. Remarkable anatomic variations in paranasal sinus region and their clinical importance. Eur J Radiol 2004;50(3):296-302.

11) Weinberger DG, Anand VK, Al-Rawi M, Cheng HJ, Messina AV. Surgical anatomy and variations of the Onodi cell. Am J Rhinol 1996; 10(6):365-70.

12) Thanaviratananich $S$, Chaisiwamongkol K, Kraitrakul S, Tangsawad W. The prevalence of an Onodi cell in adult Thai cadavers. Ear Nose Throat J 2003;82(3):200-4.

13) Kainz J, Stammberger H. Danger areas of the posterior rhinobasis. An endoscopic and anatomical-surgical study. Acta Otolaryngol 1992;112 (5):852-61.

14) Ozturan O, Yenigun A, Degirmenci N, Aksoy F, Veyseller B. Coexistence of the Onodi cell with the variation of perisphenoidal structures. Eur Arch Otorhinolaryngol 2013;270(7):2057-63.

15) Tomovic S, Esmaeili A, Chan NJ, Choudhry OJ, Shukla PA, Liu JK, et al. High-resolution computed tomography analysis of the prevalence of Onodi cells. Laryngoscope 2012;122(7):1470-3. 